\title{
Comparison of Nutrient Content, Uptake and Protein Content in Varieties of Different types of Maize Growing under Organic Farming
}

\author{
Sharvan Kumar Yadav*, Shanti Kumar Sharma², Roshan Choudhary², \\ Ravindra Kumar Jain ${ }^{2}$, Gajanand Jat ${ }^{2}$ and R. S. Choudhary ${ }^{3}$ \\ ${ }^{1}$ Department of Agronomy, RCA, MPUAT, Udaipur, India \\ ${ }^{2}$ ICAR-Network Project on Organic Farming, MPUAT, Udaipur, Rajasthan- 313001, India \\ ${ }^{3}$ Department of Agronomy MPUAT Udaipur, India \\ *Corresponding author
}

\section{A B S T R A C T}

\section{Keywords}

Maize organic farming, Variety, Uptake, Organic carbon

\begin{tabular}{|l|}
\hline Article Info \\
\hline Accepted: \\
30 May 2020 \\
Available Online: \\
10 June 2020 \\
\hline
\end{tabular}

The field experiment was conducted at the Organic Farming Unit, MPUAT, Udaipur, India to study response of different types of maize varieties grown under organic farming during kharif seasons of 2015 and 2016. The experiment comprises twelve varieties of different types of maize viz., grain maize, sweet corn, baby corn, popcorn and local maize. Results reveal that variety Misthy of sweet corn recorded significantly higher nitrogen, zinc, iron and protein content in grain at harvest on pooled basis of the both years $(1.85 \%, 45.19$ $\mathrm{mg} / \mathrm{kg}, 49.07 \mathrm{mg} / \mathrm{kg}$ and $11.57 \%$, respectively) as compared to other maize varieties. Variety Madhula of sweet corn recorded significantly highest phosphorus content in grain at harvest on pooled basis $(0.37 \%)$. Potassium content in grain at harvest on pooled basis was not-significant. Variety PHM-3 of hybrid maize recorded significantly higher total NPK uptake during 2015 and2016 (318.30 kg/ha and $338.12 \mathrm{~kg} / \mathrm{ha}$, respectively) as compared to other varieties. Variety Farmer Selection recorded significantly higher available nitrogen in soil during both the years as compared to other maize varieties. Grain variety PM-9 recorded significantly higher available phosphorus, zinc and iron in soil as compared to other varieties. Available potassium and organic carbon of different varieties of maize was found non-significant.

\section{Introduction}

Organic agriculture is being practiced in 181 countries in 112.4 million hectare area in the world. The world organic market is now \$ 97 billion (FiBL and IFOAM, 2019). Organic farming has potential benefits in terms of better soil health and quality of produce, maintenance of high yields is one of major challenge under organic farming systems (Tilman et al., 2002; Sharma et al., 2018). In present context, there is a need to search for agronomic improvement in yield of crops under organic farming by identifying suitable varieties of crops to realise its potential (Kokare et al., 2014). 
Modern varieties have been selected by plant breeders under conventional condition and they may not perform well under organic farming systems where they are grown in stressed environment without addition of external inputs that is entirely different to those in which they were selected (Ceccarelli, 1996), Murphy et al., (2007). So, there is an urgent need to identify varieties for organic farming which is believed as a stressed environment as crops are not supplied with chemicals for either supplying nutrients or to protect the crop from pests and diseases.

It has been assumed that the high yielding varieties (HYV) is not perform well under organic farming because HYV demands more nutrients which cannot be fulfilled by organic sources due to slow release pattern in the soil but experimental findings revealed that nonetheless of slow in break down and supply rate of nutrients from the organic source, they still maintaining the good organic matter content which helps the plant to uptake nutrient for longer time (Sharma and Mittra, 1991; Vanlauwe et al., 2004; Abouel Magd et $a l ., 2005)$. The variety selection for organic production plays important role in crop production. The identification of region specific cultivars of organic maize production has already been initiated in India (Layek et al., 2017).

Maize is the most important crop under organic farming due to demand in export and local demand of maize for organic poultry industry and dairy.

Therefore, the present study was conducted during 2015 and 2016to find out suitable varieties of different types of maize under organic farming.

\section{Materials and Methods}

The field experiment was conducted during kharif seasons of 2015 and 2016 at Organic
Farming Unit, Rajasthan College of Agriculture, MPUAT, Udaipur, located in Western India. The experiment was laid out in a Randomized Block Design with 12 treatments and three replications. The experiment comprises 12 varieties of different types of maize viz., Grain maize; PQPM-1, PM-9 and PHM-3, Sweet corn; Sugar-75, Madhula and Misthy, Baby corn; PM-3 and PM-5, Popcorn; VL-Amber popcorn and Amber popcorn and local varieties viz., Navjot and Farmer Selection.

The soil of experimental field was clay loam having $\mathrm{pH} 8.1$, available soil carbon $0.55 \%$, available nitrogen $220 \mathrm{~kg} / \mathrm{ha}$, available phosphorus $34.20 \mathrm{~kg} / \mathrm{ha}$, available potassium $235.50 \mathrm{~kg} / \mathrm{ha}$, available iron $3.05 \mathrm{ppm}$ and available zinc $2.5 \mathrm{ppm}$.

Different varieties of maize grown with organic management practices as per National Programme on Organic Production approved by Govt. of India (APEDA, 2017-18). All recommended agronomic, nutrient, pest and disease management practices were followed for organic farming of maize (Sharma et al., 2017). The quantity of organic source of manures was calculated based on the recommended dose of nitrogen for maize that is @ $90 \mathrm{~kg} \mathrm{ha}^{-1}$. A list of inputs used along with the quantity, time and purpose of application is mentioned in Table 1. All these inputs except neem oil were prepared at the Organic Farming Unit as per standards of organic production. Nutrient composition of different inputs is given in Table 2. Different types of maize were sown on $6^{\text {th }}$ July during 2015 and $3^{\text {rd }}$ July during 2016.

The protein content in seed was obtained by multiplying per cent nitrogen content of the seed by the factor 6.25 and expressed as per cent protein content (Simon et al., 1965). For estimation of nitrogen, phosphorus, potassium and sulphur contents, representative plant samples were collected at harvest, oven dried 
at $105^{\circ} \mathrm{C}$ for 48 hours and grind to fine powder and nutrient contents in grain and straw were estimated as per the method given in Table 3.

The uptake of nutrient by grain and stover at harvest were calculated by using following formula:

Nutrient uptake by

Grain/stover $\left(\mathrm{kg} \mathrm{ha}^{-1}\right)=$

Nutrient content in Grain/stover yield grain/stover $(\%) \quad \mathrm{x} \quad\left(\mathrm{kg} \mathrm{ha}^{-1}\right)$

\section{0}

Total nutrient uptake by the crop was computed by summing up the uptake by both grain and stover.

In order to test the significance of variation in experimental data obtained from various treatment effects, data were statistically analyzed. The critical differences were calculated to assess the significance of treatment mean, whenever the $\mathrm{F}$ test was found significant at 5 per cent level. To estimate interrelation between various characters, correlation coefficient was computed. Further, in order to establish cause and affect relationship, regression equations were calculated. All these estimates were computed by standard statistical procedure (Panse and Sukhatme, 1985).

\section{Results and Discussion}

\section{Nitrogen content in grain}

Among the maize varieties, variety Misthy recorded significantly higher nitrogen content in grain at harvest during 2015 and 2016 (1.86\% and $1.84 \%$ nitrogen, respectively) as compared to other varieties (Table 4).
However, it was found at par with variety PQPM-1 (1.81\% and $1.82 \%$ nitrogen, respectively).

Among all the varieties of grain maize, variety PQPM-1 recorded significantly higher nitrogen content in grain at harvest during 2015 and 2016 (1.81\% and $1.82 \%$ nitrogen, respectively) as compared to variety PM-9 (1.68\% and $1.66 \%$ nitrogen, respectively) and variety PHM-3 (1.58\% and $1.60 \%$ nitrogen, respectively).

Among the sweet corn varieties, variety Misthy recorded significantly higher nitrogen content in grain at harvest during 2015 and $2016 \quad(1.86 \%$ and $1.84 \%$ nitrogen, respectively) as compared to variety Madhula (1.67\% and $1.68 \%$ nitrogen, respectively) and variety Sugar-75 (1.48\% and $1.49 \%$ nitrogen, respectively).

Among the baby corn varieties, variety PM-5 recorded significantly higher nitrogen content in grain at harvest during 2015 and 2016 (1.48\% and $1.48 \%$ nitrogen, respectively) as compared to variety PM-3 (1.35\% and $1.36 \%$ nitrogen, respectively).

Among the popcorn varieties, no significant difference in nitrogen content in grain at harvest of local maize varieties was observed during 2015 and 2016.

Among the local varieties, variety Navjot gave significantly higher nitrogen content in grain at harvest during 2015 and 2016 (1.46\% and $1.44 \%$ nitrogen, respectively) as compared to variety Farmer Selection during 2015 and 2016 (1.33\% and $1.32 \%$ and 1.32 nitrogen, respectively).

\section{Nitrogen content in stover}

The data presented in Table 4 indicate that among the maize varieties, variety Madhula 
recorded significantly higher nitrogen content in stover at harvest during 2015 and 2016 $(0.71 \%$ and $0.73 \%$ nitrogen, respectively) as compared to other varieties, however, it was found at par with variety VL-Amber popcorn $(0.69 \%$ and $0.70 \%)$.

No significant difference in nitrogen content in stover of hybrid varieties of grain was found during 2015 and 2016. Among the sweet corn varieties, variety Madhula recorded significantly higher nitrogen content in stover at harvest during 2015 and 2016 $(0.71 \%$ and $0.73 \%$ nitrogen, respectively) as compared to variety Misthy $(0.64 \%$ and $0.66 \%$ and nitrogen, respectively) and variety Sugar-75 $\quad(0.63 \%$ and $0.62 \%$ nitrogen, respectively). However, among baby corn, popcorn and local maize varieties, no significant difference was found in nitrogen content in stover at harvest.

\section{Phosphorus content in grain}

Among the maize varieties, variety Madhula recorded significantly higher phosphorus content in grain at harvest during 2015 and $2016(0.36 \%$ and $0.38 \%$ phosphorus, respectively) as compared to other varieties, however, its effect was found at par with variety PQPM-1 $(0.36 \%$ and $0.37 \%$ phosphorus) (Table 4).

Among the varieties of grain maize, variety PQPM-1 recorded significantly higher phosphorus content in grain at harvest during 2015 and $2016 \quad(0.36 \%$ and $0.37 \%$ phosphorus, respectively) as compared to variety PHM-3 $(0.33 \%$ and $0.32 \%$ phosphorus, respectively) and variety PM-9 (0.30\% and $0.30 \%$ phosphorus, respectively). Among the sweet corn varieties, variety Madhula recorded significantly higher phosphorus content in grain at harvest during 2015 and $2016 \quad(0.36 \%$ and $0.38 \%$ phosphorus, respectively) as compared to variety Sugar-75 (0.35\% and $0.36 \%$ phosphorus, respectively) and variety Misthy ( $0.30 \%$ \& $0.31 \%$ phosphorus, respectively). Among the baby corn varieties, variety PM-5 recorded significantly higher phosphorus content in grain at harvest during 2015(0.29\% phosphorus) as compared to variety PM-3 (0.27\% phosphorus). However, during 2016, no significant difference was found in phosphorus content in grain at harvest. Among the popcorn varieties, no significant difference in phosphorus content in grain at harvest during 2015 and 2016 was recorded.Among the local varieties, variety Navjot gave significantly higher phosphorus content in grain at harvest during 2015 and $2016(0.26 \%$ and $0.25 \%$ phosphorus, respectively) as compared to variety Farmer Selection during 2015 and 2016 (0.60\% and $0.61 \%$ phosphorus, respectively).

\section{Phosphorus content in stover}

Variety PM-9 recorded significantly higher phosphorus content in stover at harvest during 2016 ( $0.153 \%$ phosphorus) as compared to other varieties of different types of maize. However, during 2015, variety PM-9 recorded significantly higher phosphorus content in stover at harvest $(0.141 \%$ phosphorus $)$ as compared to variety PHM-3 $(0.127 \%$ phosphorus) and it was found at par with PQPM-1 (0.135\%).

Among the sweet corn varieties, variety Sugar-75 recorded significantly higher phosphorus content in stover at harvest during 2016 (0.137\% phosphorus) as compared to variety Madhula (0.129\% phosphorus) and variety Misthy (0.109\% phosphorus). During 2015, variety Sugar-75 recorded significantly higher phosphorus content in stover at harvest (0.125\% phosphorus) as compared to variety Misthy ( $0.115 \%$ phosphorus) and it was found at par with variety Madhula $(0.121 \%$ phosphorus). Among the baby corn varieties, 
variety PM-5 recorded significantly higher phosphorus content in stover at harvest during 2015 and $2016(0.126 \%$ and 0.137 phosphorus, respectively) as compared to variety PM-3 $(0.117 \%$ and $0.125 \%$ phosphorus, respectively).Among the popcorn varieties, variety VL-Amber recorded significantly higher phosphorus content in stover at harvest during 2015 and 2016 $(0.123 \%$ and $0.133 \%$ phosphorus, respectively) as compared to variety Amber popcorn $(0.107 \%$ and $0.102 \%$ phosphorus, respectively). Among the local varieties, variety Navjot recorded significantly higher phosphorus content in stover at harvest during 2015 and $2016 \quad(0.119 \%$ and $0.124 \%$ phosphorus, respectively) as compared to variety Farmer Selection $(0.104 \%$ and $0.109 \%$ phosphorus, respectively).

\section{Potassium content in grain at harvest}

Potassium content in grain at harvest of different varieties of maize during 2015 and 2016 did not differ significantly under organic farming (Table 4).

\section{Potassium content in stover at harvest}

Among the maize varieties, variety Misthy recorded significantly higher potassium content in stover at harvest during 2015 and $2016(1.39 \%$ and $1.40 \% \mathrm{~K}$, respectively) as compared to other varieties (Table 4). However, it was found at par with variety PQPM-1 (1.37\% and 1.39\% K), PM-3 (1.33\% and $1.37 \% \mathrm{~K})$ and Navjot $(1.36 \%$ and $1.35 \%$ $\mathrm{K})$.

Among the varieties of grain maize, variety PQPM-1 recorded significantly higher potassium content in stover at harvest during 2015 and 2016 (1.37\% and $1.39 \%$ and $1.38 \mathrm{~K}$, respectively) as compared to variety PHM-3 $(1.31 \%$ and $1.34 \% \mathrm{~K}$, respectively) and variety PM-9 $(1.29 \%$ and $1.30 \% \mathrm{~K}$, respectively). Among the sweet corn varieties, variety Misthy recorded significantly higher potassium content in stover at harvest during2015 and 2016 (1.39\% and $1.40 \% \mathrm{~K}$, respectively) as compared to variety Madhula $(1.30 \%$ and $1.31 \% \mathrm{~K}$, respectively) and variety Sugar-75 (1.22 \% and $1.27 \% \mathrm{~K}$, respectively). Among the baby corn varieties, variety PM-3 recorded significantly higher potassium content in stover at harvest during $2016(1.37 \% \mathrm{~K})$ as compared to variety PM-5 (1.29 \%K).During 2015, no significant difference was found in potassium content in stover of different varieties of maize at harvest. Among the popcorn varieties, no significant difference in potassium content in stover at harvest during 2015 and 2016.Among the local varieties, variety Navjot recorded significantly higher potassium content in stover at harvest during 2015 and 2016 (1.36\% and $1.35 \%$ K, respectively) as compared to variety Farmer Selection (1.21\% and $1.22 \% \mathrm{~K}$, respectively).

\section{Zinc content in grain}

Variety Misthy recorded significantly higher zinc content in grain of maize at harvest during 2015 and $2016(45.10 \mathrm{mg} / \mathrm{kg}$ and $45.27 \mathrm{mg} / \mathrm{kg}$, respectively) as compared to other varieties (Table 5). However, it was found at par with variety PQPM-1 (44.35 $\mathrm{mg} / \mathrm{kg}$ and $44.61 \mathrm{mg} / \mathrm{kg}$, respectively), Sugar$75(42.91 \mathrm{mg} / \mathrm{kg}$ and $42.29 \mathrm{mg} / \mathrm{kg}$, respectively), Madhula (43.53 $\mathrm{mg} / \mathrm{kg}$ and $43.83 \mathrm{mg} / \mathrm{kg}$, respectively), PM-5 (43.12 $\mathrm{mg} / \mathrm{kg}$ and $43.03 \mathrm{mg} / \mathrm{kg}$, respectively), VLAmber (43.46 mg/kg and $43.31 \mathrm{mg} / \mathrm{kg}$, respectively) and Navjot $(43.60 \mathrm{mg} / \mathrm{kg}$ and $43.57 \mathrm{mg} / \mathrm{kg}$, respectively).

Among varieties of grain maize, during 2016, variety PQPM-1 recorded significantly higher zinc content in grain at harvest $(44.61 \mathrm{mg} / \mathrm{kg})$ as compared to variety PM-9 (42.29 $\mathrm{mg} / \mathrm{kg})$ and variety PHM-3 (41.11 mg/kg). However, 
during 2015, variety PQPM-1 recorded significantly higher zinc content in grain at harvest $(44.35 \mathrm{mg} / \mathrm{kg})$ as compared to variety PHM-3 (41.53 mg/kg) and it was found at par with PM-9 $(42.65 \mathrm{mg} / \mathrm{kg})$. Varieties of sweet corn and baby corn had no significant difference in zinc content in grain at harvest during 2015 and 2016. Among the popcorn varieties, during 2015 and 2016, variety VLAmber popcorn recorded significantly higher zinc content in grain at harvest $(43.46 \mathrm{mg} / \mathrm{kg}$ and $43.31 \mathrm{mg} / \mathrm{kg}$, respectively) as compared to variety Amber popcorn $(40.39 \mathrm{mg} / \mathrm{kg}$ and $40.56 \mathrm{mg} / \mathrm{kg}$, respectively).Among the local varieties, during 2015 and 2016, variety Navjot recorded significantly higher zinc content in grain at harvest $(43.60 \mathrm{mg} / \mathrm{kg}$ and $43.57 \mathrm{mg} / \mathrm{kg}$, respectively) as compared to variety Farmer Selection $(39.87 \mathrm{mg} / \mathrm{kg}$ and $39.18 \mathrm{mg} / \mathrm{kg}$, respectively).

\section{Zinc content in stover}

Variety Misthy recorded significantly higher zinc content in stover at harvest during 2015 and 2016(23.89 $\mathrm{mg} / \mathrm{kg}$ and $23.94 \mathrm{mg} / \mathrm{kg}$, respectively) as compared to other varieties (Table 5). However, it was found at par with variety PQPM-1 (23.15 $\mathrm{mg} / \mathrm{kg}$ and 23.31 $\mathrm{mg} / \mathrm{kg}$, respectively).

Among the varieties of grain maize, variety PQPM-1 recorded significantly higher zinc content in stover at harvest during 2015 and $2016(23.15 \mathrm{mg} / \mathrm{kg}$ and $23.31 \mathrm{mg} / \mathrm{kg}$, respectively) as compared to variety PM-9 (21.86 mg/kg and $21.73 \mathrm{mg} / \mathrm{kg}$, respectively) and variety PHM-3 (19.21 mg/kg and 19.15 $\mathrm{mg} / \mathrm{kg}$, respectively). Among the sweet corn varieties, variety Misthy recorded significantly higher zinc content in stover at harvest during 2015 and $2016(23.89 \mathrm{mg} / \mathrm{kg}$ and $23.94 \mathrm{mg} / \mathrm{kg}$, respectively) as compared to other varieties. The zinc content in stover of variety Madhula and sugar-75 was found at par with each other during 2015 and 2016.
Among the baby corn varieties, variety PM-5 recorded significantly higher zinc content in stover at harvest during 2015 and 2016 (21.75 $\mathrm{mg} / \mathrm{kg}$ and $21.53 \mathrm{mg} / \mathrm{kg}$, respectively) as compared to variety PM-3 (19.63 mg/kg and $19.67 \mathrm{mg} / \mathrm{kg}$, respectively). Among the popcorn varieties, variety VL-Amber popcorn recorded significantly higher zinc content in stover during 2015 and 2016 (21.43 mg/kg and $21.29 \mathrm{mg} / \mathrm{kg}$, respectively) as compared to variety Amber popcorn $(19.24 \mathrm{mg} / \mathrm{kg}$ and $19.14 \mathrm{mg} / \mathrm{kg}$, respectively).Among the local varieties, variety Navjot recorded significantly higher zinc content in stover at harvest during 2015 and $2016(21.95 \mathrm{mg} / \mathrm{kg}$ and $21.88 \mathrm{mg} / \mathrm{kg}$, respectively) as compared to variety Farmer Selection $(18.27 \mathrm{mg} / \mathrm{kg}$ and $18.19 \mathrm{mg} / \mathrm{kg}$, respectively).

\section{Iron content in grain}

Variety Misthy recorded significantly higher iron content in grain at harvest during 2015 and 2016 (49.11 mg/kg and $49.02 \mathrm{mg} / \mathrm{kg}$, respectively) as compared to other maize varieties (Table 5). However, it was found at par with the maize variety PQPM-1 (48.60 $\mathrm{mg} / \mathrm{kg}$ and $48.67 \mathrm{mg} / \mathrm{kg}$ ), PM-9 (46.98 mg/kg and $47.04 \mathrm{mg} / \mathrm{kg}$, respectively).

Among the varieties of grain maize, variety PQPM-1 recorded significantly higher iron content in grain at harvest during 2015 and 2016 (48.60 mg/kg and $48.64 \mathrm{mg} / \mathrm{kg}$, respectively) as compared to variety PHM$3(45.33 \mathrm{mg} / \mathrm{kg}$ and $45.52 \mathrm{mg} / \mathrm{kg}$, respectively) and it was found at par with variety PM-9 (46.98 mg/kg and $47.04 \mathrm{mg} / \mathrm{kg}$, respectively). Among the sweet corn varieties, variety Misthy recorded significantly higher iron content in grain at harvest during 2015 and $2016(49.11 \mathrm{mg} / \mathrm{kg}$ and $49.02 \mathrm{mg} / \mathrm{kg}$, respectively) as compared to variety Madhula (46.63 mg/kg and $46.59 \mathrm{mg} / \mathrm{kg}$, respectively) and Sugar-75 (44.25 mg/kg and $44.37 \mathrm{mg} / \mathrm{kg}$, respectively).Among the baby corn and 
popcorn varieties, no significant difference in iron content in grain at harvest during 2015 and 2016.Among the local varieties, variety Navjot recorded significantly higher zinc content in grain at harvest during 2015 and 2016 (45.05 mg/kg and $45.14 \mathrm{mg} / \mathrm{kg}$, respectively) as compared to variety Farmer Selection $(42.58 \mathrm{mg} / \mathrm{kg}$ and $42.65 \mathrm{mg} / \mathrm{kg}$, respectively).

\section{Iron content in stover}

Iron content in stover at harvest of different varieties of maize grown under organic farming during 2015 and 2016 was found non-significant (Table 5).

\section{Protein content in grain}

Variety Misthy recorded significantly higher protein content in grain at harvest during 2015 and 2016 (116.30\% and $11.53 \%$, respectively) as compared to other maize varieties (Table 5). However, it was found at par with variety PQPM-1 (11.28\% and 11.37\%, respectively).

Among the varieties of grain maize, variety PQPM-1 recorded significantly higher protein content in grain at harvest during 2015 and 2016 (11.28\% and $11.37 \%$, respectively) as compared to variety PM-9 (10.49\% and $10.41 \%$, respectively) and variety $\mathrm{PHM}-3$ (9.90\% and $10.01 \%$, respectively). Among the sweet corn varieties, variety Misthy recorded significantly higher protein content in grain at harvest during 2015 and 2016 (11.60\% and $11.53 \%$, respectively) as compared to variety Madhula (10.43\% and $10.51 \%$, respectively) and sugar-75 (9.26\% and $9.32 \%$, respectively). Among the baby corn varieties, variety PM-5 recorded significantly higher protein content in grain at harvest during 2015 and 2016 (9.26\% and $9.22 \%$, respectively) as compared to variety PM-3 (8.44\% and $8.48 \%$, respectively). Among the popcorn varieties, no significant difference in protein content in grain at harvest was observed during 2015 and 2016.Among the local varieties, variety Navjot recorded significantly higher protein content in grain at harvest during 2015 and 2016 (9.04\% and $8.99 \%$, respectively) as compared to variety Farmer Selection $(8.28 \%$ and $8.24 \%$, respectively).

\section{Protein content in stover}

Variety Madhula recorded significantly higher protein content in stover at harvest during $2016(4.58 \%)$ as compared to other varieties. However, it was found at par with variety VL-Amber popcorn (4.38\%). During 2015, variety Madhula recorded significantly higher protein content in stover at harvest $(4.44 \%)$ as compared to other varieties, but it was at par with variety PM-9 (4.24\%) and variety VL-Amber popcorn (4.33\%). Among the varieties of grain maize, no significant difference in protein content in stover at harvest was recorded during 2015 and 2016.Among the sweet corn varieties, variety Madhula recorded significantly higher protein content in stover at harvest during 2015 and 2016 (4.44\% and 4.58\%, respectively) as compared to variety Misthy $(3.99 \%$ and $4.10 \%$, respectively) and Sugar-75 (3.91\% and $3.87 \%$, respectively).However, no significant difference in protein content of stover of varieties of baby corn, pop corn and local varieties was recorded during 2015 and 2016.

\section{NPK uptake}

There was a significant variation in uptake of total NPK by varieties of different types of maize. The maximum uptake of total nitrogen, phosphorus and potassium during 2015 and 2016 (318.30 kg/ha and 338.12 $\mathrm{kg} / \mathrm{ha}$, respectively) was recorded by the variety PHM-3 as compared to other varieties, however, it was found at par with variety Sugar-75 (292.87 kg/ha) during 2015 (Table $6)$. 
Among the varieties of grain maize, variety PHM-3 recorded significantly higher total NPK uptake during 2015 and 2016 (318.30 $\mathrm{kg} / \mathrm{ha}$ and $338.12 \mathrm{~kg} / \mathrm{ha}$, respectively) as compared to variety PQPM-1 and PM-9. Among the sweet corn varieties, variety Sugar-75 recorded significantly higher total NPK uptake during 2015 (292.87 kg/ha) as compared to variety Madhula $(154.81 \mathrm{~kg} / \mathrm{ha})$ and Misthy $(218.10 \mathrm{~kg} / \mathrm{ha})$, however, during 2016, there was found no significant difference.No significant difference was found in total NPK uptake during 2015 and
2016 among the baby corn varieties. Among the popcorn varieties, variety VL-Amber popcorn recorded significantly higher total NPK uptake during 2015 and 2016 (183.44 $\mathrm{kg} / \mathrm{ha}$ and $138.98 \mathrm{~kg} / \mathrm{ha}$, respectively) as compared to variety Amber popcorn (71.27 $\mathrm{kg} / \mathrm{ha}$ and $102.76 \mathrm{~kg} / \mathrm{ha}$, respectively). Among local varieties, variety Farmer Selection recorded significantly higher total NPK uptake during 2015 and $2016(214.54 \mathrm{~kg} / \mathrm{ha}$ and $251.50 \mathrm{~kg} / \mathrm{ha}$, respectively) as compared to variety Navjot $(175.86 \mathrm{~kg} / \mathrm{ha}$ and 214.83 $\mathrm{kg} / \mathrm{ha}$, respectively).

Table.1 Organic inputs and materials used in organic farming of maize

\begin{tabular}{|l|l|l|l|}
\hline Input & Time of application & Amount used & Purpose of application \\
\hline NADEP compost & At the time sowing & $6000 \mathrm{~kg} \mathrm{ha}^{-1}$ & Nutrient management \\
\hline Vermicompost & At the time sowing & $3000 \mathrm{~kg} \mathrm{ha}^{-1}$ & Nutrient management \\
\hline Neem cake & $\begin{array}{l}1 / 2 \text { at the time of sowing and } 1 / 2 \\
\text { tasselling stage }\end{array}$ & $580 \mathrm{~kg} \mathrm{ha}^{-1}$ & $\begin{array}{l}\text { Nutrient and pest } \\
\text { management }\end{array}$ \\
\hline Vermiwash & 25 DAS and 45 DAS & $10 \%$ & Nutrient management \\
\hline BD 500 & Day before sowing in evening & $75 \mathrm{~g} \mathrm{ha}^{-1}$ & Soil and plant health \\
\hline $\begin{array}{l}\text { Yellow mataka } \\
\text { trap (No.) }\end{array}$ & 15 DAS & $16 \mathrm{ha}^{-1}$ & $\begin{array}{l}\text { For insects and pest } \\
\text { monitoring }\end{array}$ \\
\hline Neem oil & 20 DAS & $0.3 \%$ & Pest management \\
\hline
\end{tabular}

Table.2 Nutrient composition of different inputs

\begin{tabular}{|l|c|c|c|}
\hline Particulars & Vermicompost & Neem cake & NADEP compost \\
\hline $\mathbf{N} \%$ & 2.99 & 5.22 & 1.5 \\
\hline $\mathbf{P}_{\mathbf{2}} \mathbf{O}_{\mathbf{5}} \%$ & 0.43 & 1.08 & 0.37 \\
\hline $\mathbf{K}_{\mathbf{2}} \mathbf{O} \%$ & 2.09 & 1.48 & 1.14 \\
\hline
\end{tabular}

Table.3 Methods adopted for plant analysis

\begin{tabular}{|c|c|c|c|}
\hline S. No. & Determination & Methods & Reference \\
\hline 1. & Nitrogen & $\begin{array}{l}\text { Colorimetric method using spectronic } 20 \text { after } \\
\text { development of colour with Nesseler's reagent }\end{array}$ & Snell and Snell (1949) \\
\hline 2. & Phosphorus & $\begin{array}{l}\text { Vanadomolybdo phosphoric acid yellow colour } \\
\text { method }\end{array}$ & Jackson (1973) \\
\hline 3. & Potassium & Flame Photometer method & Jackson (1973) \\
\hline 4. & Zinc and Iron & Estimation on AAS & Lindsay and Norvell (1978) \\
\hline 5. & Protein content & $\begin{array}{l}\text { Nitrogen content in seed multiplied by factor } \\
6.25 \text {. }\end{array}$ & A.O.A.C. (1960) \\
\hline
\end{tabular}


Table.4 NPK content in grain and stover of maize varieties at harvest grown under organic farming (2015 and 2016)

\begin{tabular}{|c|c|c|c|c|c|c|c|c|c|c|c|c|}
\hline \multirow[t]{2}{*}{ Variety } & \multicolumn{2}{|c|}{$\begin{array}{c}\mathrm{N} \text { content in grain } \\
(\%)\end{array}$} & \multicolumn{2}{|c|}{$\begin{array}{c}\mathrm{N} \text { content in stover } \\
(\%)\end{array}$} & \multicolumn{2}{|c|}{$\begin{array}{c}P \text { content in grain } \\
(\%)\end{array}$} & \multicolumn{2}{|c|}{$\begin{array}{c}\text { P content in stover } \\
(\%)\end{array}$} & \multicolumn{2}{|c|}{$\begin{array}{c}K \text { content in grain } \\
(\%)\end{array}$} & \multicolumn{2}{|c|}{$\begin{array}{c}\text { K content in stover } \\
(\%)\end{array}$} \\
\hline & 2015 & 2016 & 2015 & 2016 & 2015 & 2016 & 2015 & 2016 & 2015 & 2016 & 2015 & 2016 \\
\hline \multicolumn{13}{|l|}{ Grain maize } \\
\hline PQPM-1 & 1.81 & 1.82 & 0.66 & 0.64 & 0.36 & 0.37 & 0.135 & 0.145 & 0.38 & 0.40 & 1.37 & 1.39 \\
\hline PM - 9 & 1.68 & 1.66 & 0.68 & 0.68 & 0.30 & 0.30 & 0.141 & 0.153 & 0.40 & 0.41 & 1.29 & 1.30 \\
\hline PHM-3 & 1.58 & 1.60 & 0.67 & 0.67 & 0.32 & 0.33 & 0.127 & 0.132 & 0.35 & 0.37 & 1.31 & 1.34 \\
\hline \multicolumn{13}{|l|}{ Sweet corn } \\
\hline Sugar 75 & 1.48 & 1.49 & 0.63 & 0.62 & 0.35 & 0.36 & 0.125 & 0.137 & 0.39 & 0.40 & 1.22 & 1.27 \\
\hline Madhula & 1.67 & 1.68 & 0.71 & 0.73 & 0.36 & 0.38 & 0.121 & 0.129 & 0.41 & 0.42 & 1.30 & 1.31 \\
\hline Misty & 1.86 & 1.84 & 0.64 & 0.66 & 0.30 & 0.31 & 0.115 & 0.109 & 0.40 & 0.41 & 1.39 & 1.40 \\
\hline \multicolumn{13}{|l|}{ Baby corn } \\
\hline PM- 3 & 1.35 & 1.36 & 0.65 & 0.66 & 0.27 & 0.29 & 0.117 & 0.125 & 0.35 & 0.37 & 1.33 & 1.37 \\
\hline PM- 5 & 1.48 & 1.48 & 0.67 & 0.68 & 0.29 & 0.30 & 0.126 & 0.137 & 0.38 & 0.40 & 1.27 & 1.29 \\
\hline \multicolumn{13}{|l|}{ Pop corn } \\
\hline VL Amber & 1.41 & 1.42 & 0.69 & 0.70 & 0.23 & 0.24 & 0.123 & 0.133 & 0.32 & 0.33 & 1.29 & 1.30 \\
\hline Amber pop & 1.39 & 1.40 & 0.66 & 0.68 & 0.22 & 0.22 & 0.107 & 0.102 & 0.38 & 0.39 & 1.27 & 1.30 \\
\hline \multicolumn{13}{|l|}{ Local } \\
\hline Navjot & 1.46 & 1.44 & 0.63 & 0.63 & 0.26 & 0.25 & 0.119 & 0.124 & 0.43 & 0.42 & 1.36 & 1.35 \\
\hline Farmers sel & 1.33 & 1.32 & 0.60 & 0.61 & 0.21 & 0.22 & 0.104 & 0.109 & 0.31 & 0.33 & 1.21 & 1.22 \\
\hline SEm \pm & 0.022 & 0.029 & 0.012 & 0.012 & 0.005 & 0.005 & 0.002 & 0.002 & 0.007 & 0.007 & 0.024 & 0.024 \\
\hline CD at $5 \%$ & 0.066 & 0.084 & 0.034 & 0.035 & 0.015 & 0.015 & 0.006 & 0.006 & NS & NS & 0.069 & 0.070 \\
\hline
\end{tabular}


Table.5 Zn, Fe and protein content in grain and stover of varieties of different types of maize grown under organic farming (2015 and 2016)

\begin{tabular}{|c|c|c|c|c|c|c|c|c|c|c|c|c|}
\hline \multirow[t]{2}{*}{ Variety } & \multicolumn{2}{|c|}{$\begin{array}{l}\text { Zn content in grain } \\
\qquad(\mathrm{mg} / \mathbf{k g})\end{array}$} & \multicolumn{2}{|c|}{$\begin{array}{l}\text { Zn content in stover } \\
(\mathrm{mg} / \mathrm{kg})\end{array}$} & \multicolumn{2}{|c|}{$\begin{array}{l}\text { Fe content in grain } \\
(\mathbf{m g} / \mathbf{k g})\end{array}$} & \multicolumn{2}{|c|}{$\begin{array}{c}\text { Fe content in stover } \\
(\mathrm{mg} / \mathrm{kg})\end{array}$} & \multicolumn{2}{|c|}{$\begin{array}{l}\text { Protein content in } \\
\text { grain }(\%)\end{array}$} & \multicolumn{2}{|c|}{$\begin{array}{l}\text { Protein content in } \\
\text { stover }(\%)\end{array}$} \\
\hline & 2015 & 2016 & 2015 & 2016 & 2015 & 2016 & 2015 & 2016 & 2015 & 2016 & 2015 & 2016 \\
\hline \multicolumn{13}{|l|}{ Grain maize } \\
\hline PQPM - 1 & 44.35 & 44.61 & 23.15 & 23.31 & 48.60 & 48.67 & 185.51 & 185.78 & 11.28 & 11.37 & 4.11 & 4.01 \\
\hline PM - 9 & 42.65 & 42.29 & 21.86 & 21.73 & 46.98 & 47.04 & 184.90 & 185.03 & 10.49 & 10.41 & 4.24 & 4.28 \\
\hline PHM - 3 & 41.53 & 41.11 & 19.21 & 19.15 & 45.33 & 45.52 & 183.11 & 183.19 & 9.90 & 10.01 & 4.17 & 4.21 \\
\hline \multicolumn{13}{|l|}{ Sweet corn } \\
\hline Sugar 75 & 42.91 & 43.02 & 21.14 & 21.33 & 44.25 & 44.37 & 181.23 & 181.44 & 9.26 & 9.32 & 3.91 & 3.87 \\
\hline Madhula & 43.53 & 43.83 & 21.92 & 21.89 & 46.63 & 46.59 & 185.89 & 185.61 & 10.43 & 10.51 & 4.44 & 4.58 \\
\hline Misty & 45.10 & 45.27 & 23.89 & 23.94 & 49.11 & 49.02 & 186.25 & 186.01 & 11.60 & 11.53 & 3.99 & 4.10 \\
\hline \multicolumn{13}{|l|}{ Baby corn } \\
\hline PM- 3 & 41.51 & 41.67 & 19.63 & 19.67 & 43.75 & 43.81 & 179.80 & 179.95 & 8.44 & 8.48 & 4.03 & 4.13 \\
\hline PM- 5 & 43.12 & 43.03 & 21.75 & 21.53 & 44.82 & 44.79 & 182.81 & 182.66 & 9.26 & 9.22 & 4.19 & 4.27 \\
\hline \multicolumn{13}{|l|}{ Pop corn } \\
\hline VL Amber & 43.46 & 43.31 & 21.43 & 21.29 & 44.69 & 44.74 & 181.81 & 181.45 & 8.81 & 8.88 & 4.33 & 4.38 \\
\hline $\begin{array}{l}\text { Amber } \\
\text { popcorn }\end{array}$ & 40.39 & 40.56 & 19.24 & 19.14 & 43.91 & 43.88 & 179.71 & 179.24 & 8.66 & 8.76 & 4.13 & 4.23 \\
\hline \multicolumn{13}{|l|}{ Local } \\
\hline Navjot & 43.60 & 43.57 & 21.95 & 21.88 & 45.05 & 45.14 & 181.96 & 182.05 & 9.04 & 8.99 & 3.92 & 3.96 \\
\hline Farmers sel & 39.87 & 39.18 & 18.27 & 18.19 & 42.58 & 42.65 & 177.23 & 176.67 & 8.28 & 8.24 & 3.76 & 3.83 \\
\hline SEm \pm & 0.770 & 0.770 & 0.373 & 0.386 & 0.828 & 0.828 & 3.287 & 3.283 & 0.174 & 0.180 & 0.073 & 0.075 \\
\hline CD at $5 \%$ & 2.259 & 2.259 & 1.094 & 1.131 & 2.429 & 2.428 & 9.640 & NS & NS & 0.527 & 0.215 & 0.219 \\
\hline
\end{tabular}


Table.6 Total NPK uptake by varieties of different types of maize at harvest grown under organic farming (2015 and 2016)

\begin{tabular}{|l|c|c|}
\hline \multirow{2}{*}{ Variety } & \multicolumn{2}{|c|}{ Total NPK uptake (kg/ha) } \\
\cline { 2 - 3 } & $\mathbf{2 0 1 5}$ & $\mathbf{2 0 1 6}$ \\
\hline Grain maize & \multicolumn{2}{|c|}{} \\
\hline Pratap QPM Hybrid - 1 & 278.94 & 317.89 \\
\hline PM - 9 & 223.74 & 251.71 \\
\hline Pratap Hybrid Maize - 3 & 318.30 & 338.12 \\
\hline Sweet corn & & \\
\hline Sugar 75 & 292.87 & 220.45 \\
\hline Madhula & 154.81 & 199.16 \\
\hline Misty & 218.10 & 215.32 \\
\hline Baby corn & & \\
\hline PM- 3 & 110.08 & 94.52 \\
\hline PM- 5 & 97.16 & 80.94 \\
\hline Pop corn & & \\
\hline VL Amber pop corn & 183.44 & 138.98 \\
\hline Amber pop corn & 71.27 & 102.76 \\
\hline Local & & \\
\hline Navjot & 175.86 & 214.83 \\
\hline Farmers Selection & 214.54 & 251.50 \\
\hline SEm \pm & 8.994 & 9.064 \\
\hline CD at 5 \% & 26.379 & 26.583 \\
\hline & & \\
\hline
\end{tabular}


Fig.1 Total NPK uptake by varieties of varieties of different types of maize at harvest grown under organic farming (2015 and 2016)

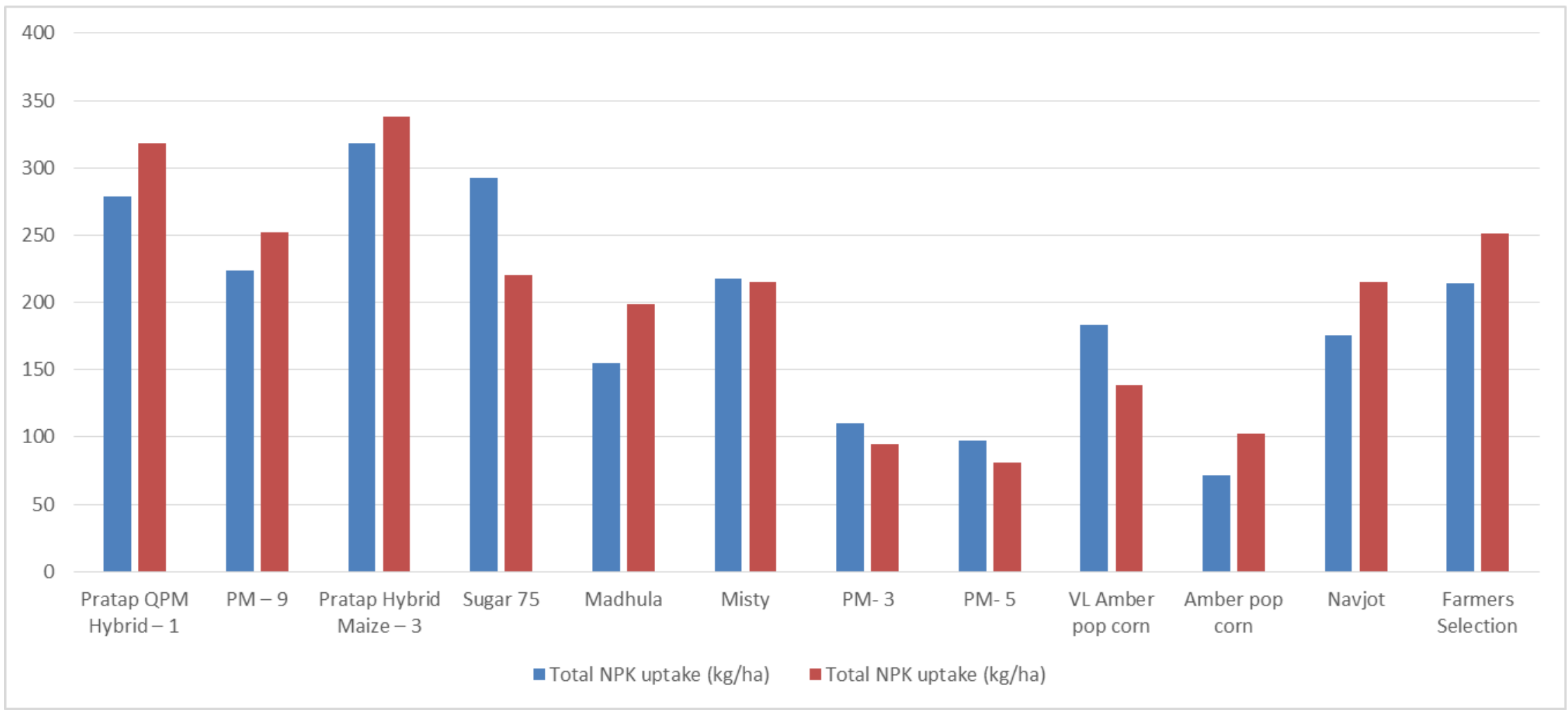


Higher soil available $\mathrm{N}$ content after harvest of maize was observed under local variety Farmer Selection on pooled basis $(348.83 \mathrm{~kg}$ $\mathrm{ha}^{-1}$ ) followed by Navjot (325.83), PM-5 $(316.70 \mathrm{~kg} / \mathrm{ha}), \quad \mathrm{PM}-3 \quad(315.14 \mathrm{~kg} / \mathrm{ha})$, Madhula (309.14 kg/ha) and Misthy (307.34 $\mathrm{kg} / \mathrm{ha}$ ) and it ranged from 293.27 to $348.83 \mathrm{~kg}$ $\mathrm{ha}^{-1}$ (Table 7). The variety PM-9 recorded significantly higher available $\mathrm{P}$ of $37.15 \mathrm{~kg}$ $\mathrm{ha}^{-1}$ as compared to other varieties, however, it was found at par with variety PM-5 (36.12 $\mathrm{kg} / \mathrm{ha}$ ) and the lowest soil available phosphorus was recorded in variety Farmer Selection (22.09 kg ha ${ }^{-1}$ ). Available K in soil was higher in the variety Farmer Selection on pooled basis of both the years $\left(438 \mathrm{~kg} \mathrm{ha}^{-1}\right)$ as compared to other varieties and it was found at par with variety Navjot (425.83 kg/ha).

It may be due to lower uptake of $\mathrm{N}$ from soil due to lower yield potential of these varieties. Application of FYM, NADEP, biodynamic manures, oil cake and microbial culture helps in proper nutrition and maintenance of soil fertility in maize fields when applied at proper doses replenishing the most deficient macroand micro nutrients which in turn help in getting the optimum grain yield and harvest index of maize varieties. Organic manures were reported to improve the soil organic carbon, available $\mathrm{N}, \mathrm{P}$ and $\mathrm{K}$ in soil, thereby sustaining the soil health (Das et al., 2010).

During 2015, 2016 and on pooled basis, variety Misthy recorded significantly higher protein content in seed $(11.60 \%, 11.53 \%$ and $11.57 \%$, respectively) as compared to other varieties, however, it was found statistically at par with variety PQPM-1 (11.28\%, $11.37 \%$ and $11.33 \%$, respectively) (Table 5). This difference in protein content might be attributed to difference in genetic makeup and nitrogen content of varieties which influence in the protein content (Ali et al., 2008). Similar results were reported by Hailu et al., (2008) in carrot and Melkamu et al., (2008) in tomato. Nutrient uptake varies from crop to crop and variety to variety under different crop management conditions (Fess and Benedito, 2018). Nutrient uptake by plants depends on the soil solution phase, plant genetic characters, ability to absorption of nutrients by plants, response of nutrients and soil moisture availability. Cultivars with increased efficiency of uptake and utilization of soil nutrients are likely to have positive environmental effects. Root characteristics of varieties also decide uptake of nutrients.

Uptake of $\mathrm{N}, \mathrm{P}$ and $\mathrm{K}$ of different types of maize and their varieties varied significantly under organic management (Table 6). With respect to $\mathrm{N}, \mathrm{P}$ and $\mathrm{K}$ uptake, the variety PHM-3 recorded significantly maximum uptake during 2015, 2016 and on pooled basis at harvest as compared to all the other varieties. This might be attributed to difference in root characteristics, growth pattern and dry matter accumulation of different types of maize and their varieties (Krannitz et al., 1991 and Barber, 1995). Sangshetty (2006) observed varietal variation in the nutrient uptake of $\mathrm{N}$ among the cotton cultivars. The variety PHM-3 recorded significantly higher dry matter accumulation by grain at tasseling stage during 2015, 2016 and on pooled basis (83.33 g/plant, 81.00 $\mathrm{g} /$ plant and $82.17 \mathrm{~g} /$ plant, respectively) as compared to other maize varieties. This might have resulted in higher uptake of nutrients $(\mathrm{N}$, $\mathrm{P}, \mathrm{K}$ and micronutrients) in comparison to other varieties.

The differences among the cultivars of a species in $\mathrm{P}$ uptake can be attributed to the differences in root growth (Krannitz et al., 1991 and Barber, 1995).

It is a well known fact that the nutrient uptake is a function of nutrient content and yield (grain and straw). Moreover, nutrient content is dependent upon various factors like nutrient acquisition characteristics of the variety, root characteristics and secretion of root exudates 
to favour microbial growth for making the nutrient available in the rhizosphere. The rice variety NDR-359 produced higher grain and straw yield than rest of the varieties tested so could have led to higher uptake of $\mathrm{N}, \mathrm{P}$ and $\mathrm{K}$ (Shing et al., 2017).

\section{Acknowledgements}

We acknowledge the support of Maharana Pratap University of Agricultural and Technology, Udaipur (Rajasthan) India and ICAR Network Project on Organic Farming for this study. The research was funded by ICAR Network Project on Organic Farming, Indian Institute of Farming System Research, Modipuram, Meerut, India.

\section{References}

A.O. A. C. 1960. Official methods of analysis. $10^{\text {th }}$ Edition, Association of Official Analytical Chemists, Washington DC.

AbouelMagd, M. M., Mohamed, H. A., Fawzy, Z. F.(2005). Relationship growth, yield of broccoli with increasing $\mathrm{N}, \mathrm{P}$ or $\mathrm{K}$ ratio in a mixture of NPK fertilizers (Brassico oleracea var italicaplenck). Annals of Agriculture Science Moshtohor Journal, 43(2), 791-805.

Ali, Y., Atta, B. M., Akhter, J., Monneveux, P. and Lateef, Z. (2008). Genetic variability, association and diversity studies in wheat (Triticum aestivum L.) germplasm. Pakisthan Journal of Botany, 40(5), 2087-2097.

Barber, S. A. (1995). Soil Nutrient Bio availability. A Mechanistic Approach, $2^{\text {nd }}$ Edn. John Wiley and Sons, New York.

Ceccarelli, S.S. (1996). Adaptation to low/high input cultivation. Euphytica, 92, 203-214.

Das, A., Patel, D. P., Munda, G. C. and Ghosh, P. K. (2010). Effect of organic and inorganic sources of nutrients on yield, nutrient uptake and soil fertility of maize (Zea mays) mustard (Brassica campestris) cropping system. Indian Journal of Agricultural Sciences, 80, 85-88.

Fess, T. L. and Benedito, V. A. (2018). Organic versus conventional cropping sustainability:
A comparative system analysis. Sustainability, 10(272), 1-42.

Hailu, S., Seyoum, T. and Dechassa, N. (2008). Effect of combined application of organic $\mathrm{P}$ and inorganic $\mathrm{N}$ fertilizers on post-harvest quality of carrot. African Journal of Biotechnology, 7(13): 2187-2196.

Jackson, M. L. (1973). Soil Chemical Analysis. Ed. 2. Prentice Hall Inc. Pvt. Ltd., New Delhi. pp. 134-82.

Kokare, A., Legzdina, L., Beinarovica, I., Maliepaard, C., Niks, R.E. and Bueren, E.T.L. (2012). Performance of spring barley (Hordeum vulgare) varieties under organic and conventional conditions. Euphytica, 197(2), 279-293.

Krannitz, P. G., Aarssen, L. W. and Lefebvre. D. D. (1991). Short term competition for phosphate between two genotypes of Arabidopsis thaliana (L.). New Phytologist, 119(3), 389-396.

Layek, J., Ramkrushna, G. I., Suting, D., Ngangom, B., Krishnappa, R., Utpal, D. and Das, A. (2017). Evaluation of Maize Cultivars for their Suitability under Organic Production System in North Eastern Hill Region of India. Indian Journal of Hill Farming, 29(2), 19-24.

Lindsay, W. L. and Norvell, W. A. (1978). Development of a DTPA soil test for zinc, iron, manganese and copper. Soil Science Society of America Journal, 42, 421-428.

Melkanu, M., Seyoum, T. and Woldetsadik, K. (2008). Effect of pre and post-harvest treatments on changes in sugar content of tomato. African Journal of Biotechnology, 7(8), 1139-1144.

Murphy, K. M., Campbell, K. G., Lyon, S. R. and Jones, S. S. (2007). Evidence of varietal adaptation to organic farming systems. Field Crops Research, 102, 172-177.

Panse, V. G. and Sukhatme, P. V. 1985. Statistical Methods for Agricultural workers, I.C.A.R., New Delhi.

Ravishankar, N., Panwar, A. S., Prasad, K., Kumar, V. and Bhaskar, S. (2018). Organic farming crop production guide, Network Project on Organic Farming, ICAR- Indian Institute of Farming System Research, Modipuram, Meerut-250110, Uttar Pradesh, India. Pp. 586. 
Sangshetty, (2006). Response of the cotton genotypes to different sources of organic manures under organic production system. M.Sc. (Ag). Thesis. UAS, Dharwad, Karnataka.

Sharma, A. R., Mitra, B. N. (1991). Relative efficiency of different organic materials and $\mathrm{N}$ fertilizer in wetland rice culture. Thailand Journal of Agricultural Science, 22(2), 145151.

Sharma, S. K, Roshan Choudhary, Yadav, S. K. and Jain, R. K. (2018). Productivity and economics of maize based cropping systems under organic cultivation. Symposium on "Doubling farmer's income through agronomic interventions under changing scenario" organised by Indian Society of Agronomy and MPUAT during 24-26 October, 2018.

Simon, T. E., Adsir, C. R., Kohler, G. P., Dabald,
H. A., Kestar, F. B. and Hlick, J. T. (1965). Quality evaluation studies of foreign and domestic rices. Technical Bulletin No. 1331, USDA, pp. 1-6.

Snell, P. D. and Snell, G. T. (1949). Colorimetric method of analysis, $3^{\text {rd }}$ Ed. Vol. II-D, Van Mastrand CO. Inc. New York.

Tilman, D., Cassman, K.G., Matson, P.A., Naylor, R. and Polasky, S. (2002). Agricultural sustainability and intensive production practices. Nature, 418, 671-677.

Vanlauwe B. (2004). Integrated soil fertility management research at TSBF: the framework, the principles, and their application. In: Managing Nutrient Cycles to Sustain Soil Fertility in sub-Saharan Africa (Eds: Bationo A.), Academy Science Publishers, Nairobi.; Pp. 25-42.

\section{How to cite this article:}

Sharvan Kumar Yadav, Shanti Kumar Sharma, Roshan Choudhary, Ravindra Kumar Jain, Gajanand Jat and Choudhary, R. S. 2020. Comparison of Nutrient Content, Uptake and Protein Content in Varieties of Different types of Maize Growing under Organic Farming. Int.J.Curr.Microbiol.App.Sci. 9(06): 3798-3812. doi: https://doi.org/10.20546/ijcmas.2020.906.451 